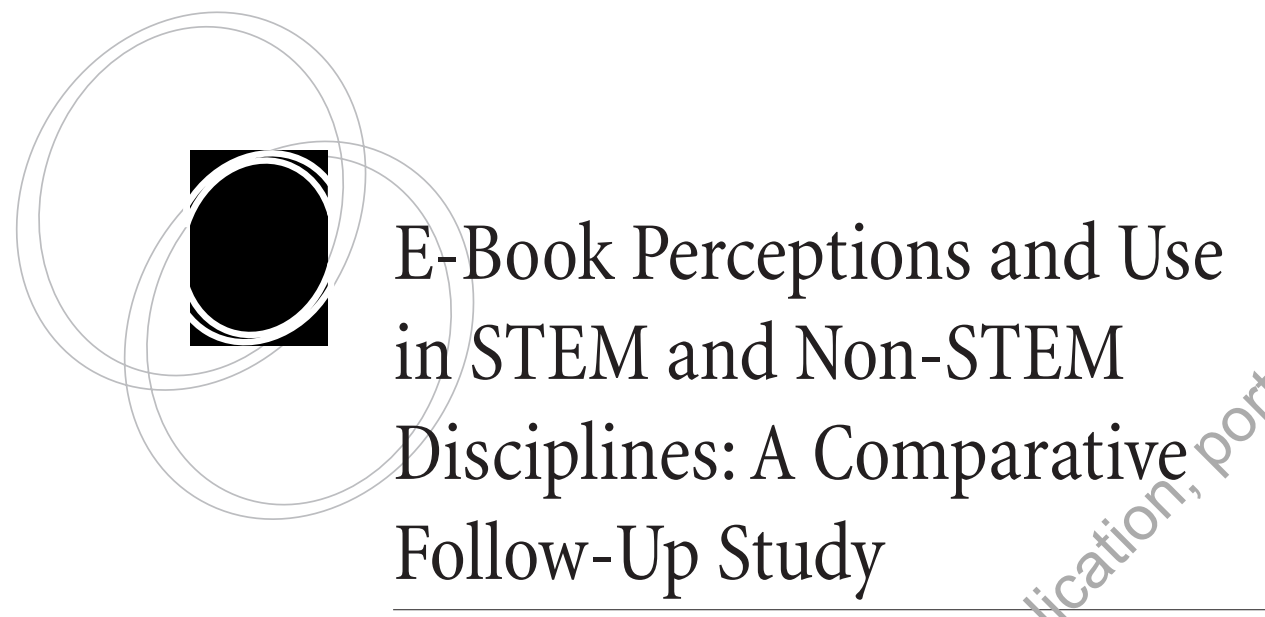

Alexander J. Carroll, Kelsey Corlett-Pivera, Timothy Hackman, and Jinwang Zou

abstract: This article describes the results of a survey that gathered data on perceptions and use of e-books from undergraduate students, graduate sturiefis, faculty, and staff. The investigators analyzed the results based on user affiliate status and ibject discipline and compared the results with the findings of a similar, smaller-scale study donducted in 2012. The study concludes with a discussion of the major findings and their implisations for academic libraries and publishers, as well as areas for further inquiry.

\title{
Introduction
}

$\mathrm{T}$ alk to any gro(1) of academic librarians, and you will hear a range of opinions on e-books: thdi advantages and disadvantages compared to print books; the ways in whict they solve or create all manner of problems for libraries; how they will either spell we end of academic research or will open up a new era of scholarly inquiry. In 2012, the authors conducted a survey of the students and faculty in three colleges at the Unv versity of Maryland in College Park to test whether the scholars who use these resources shared those opinions. That survey provided valuable data regarding preferences for e-books among students and faculty in the arts, humanities, and social sciences. The findings were published in portal in 2014. In the three years since the original survey, the e-book landscape has evolved rapidly. E-book collections in academic libraries in general, and at the University of Maryland (UMD) Libraries in particular, have grown dramatically. Consequently, the authors administered a follow-up survey to update and

portal: Libraries and the Academy, Vol. 16, No. 1 (2016), pp. 131-163.

Copyright (C) 2015 by Johns Hopkins University Press, Baltimore, MD 21218. 
expand upon the original findings. As with the original, the current survey had several guiding research questions, including:

- Do (or how often do) University of Maryland faculty and students identify, access, and use e-books for academic purposes?

- For what types of material (monographs, edited collections, conference proceedings, reference works, and the like) do faculty and students prefer the UMD Libraries to buy e-books? For what materials would they like the libraries to buy print books?

- How do use and attitudes compare among respondents who do or do not use the physical libraries?

- How do use and attitudes compare among respondents of different statuses (faculty, graduate student, or undergraduate student)?

The authors added two research questions for this study:

- How do use and attitudes of respondents in science, technofogy, engineering, and math (STEM) disciplines compare with those of respondents in non-STEM disciplines?

- How do use and attitudes among respondents compare with previously published studies, including the authors' previous e-books s? rvey?

The data collected will be valuable to academic librarians and will add to the growing body of literature on academic user opinions of -books. Additionally, the findings will be useful to librarians involved in the ongoing work of negotiating with publishers to ensure e-book platforms and business moidels that are usable, equitable, and sustainable. For a brief overview of the implications of this study for collection managers, see Table 3 .

\section{Institutional Context}

The University of Marylar (d) is a major public research university in College Park, less than ten miles north of Washington, D.C. It is the flagship institution of the University System of Maryland find offers 91 undergraduate majors and more than 200 graduate degrees through 3 ograms in twelve colleges and schools. The university has a total enrollment of@r, 248 (26,538 undergraduate and 10,710 graduate); a tenured or tenuretrack facul'ty of 1,511, among 4,467 total faculty; and a staff of 5,494.

\section{Literature Review}

Withe spring of 2012, the UMD Libraries surveyed library users on their use and perceptions of e-books. ${ }^{1}$ While participants in that survey represented users in each affiliate status (undergraduates, graduate students, faculty, and staff), the study included only a handful of the subject disciplines (the colleges of Arts and Humanities, Behavioral and Social Sciences, and Education) at UMD. Since that study's publication, the design of limiting subject participation based on subject discipline or affiliate status has remained a widely used methodology for studying e-book usage and perceptions because it allows for comparative analysis across different disciplines and statuses. The literature provides plentiful examples of such studies. ${ }^{2}$ 
Yet, considering the wide range of academic programs at UMD, the 2012 e-book study, which did not include users from STEM disciplines, left considerable room for further research. While users within STEM disciplines are generally presumed to be more accepting of e-books, recent studies indicate that they may share many of the same frustrations as users in the humanities and social sciences. ${ }^{3}$ If similar aspects of e-book usage frustrate users across different disciplines, libraries might be better served by examining e-book usage and perceptions at a macro level. Many of the large studies in this area date from more than five years ago. ${ }^{4}$ Moreover, the user interface designs for e-book platforms change so rapidly that such studies provide only "a snapshot of platforms at a certain moment," rather than definitive accounts of e-books and the academy. ${ }^{5}$ Consequently, the

While users within STEM disciplines are generally presumed to be more accepting of e-books, recent studie? indicate that they may share many of the same frustrations as users in the humanities and socialsciences. conclusions drawn from these studies may not reflect user reactions to the most recent changes in e-book availability and platforms, or the increased availability of mobile devices that support e-books. ${ }^{6}$

Despite numerous studies of e-books and acadenic libraries, a number of points of contention remain. One such disagreement is thefrimpact of e-reader ownership on user attitudes toward e-books. The market penetretion of e-readers has increased dramatically, with Forbes estimating that Amazon sgld 20 million Kindle devices in 2013 alone. ${ }^{7}$ One of the major findings of the UMD I braries 2012 study was that e-reader ownership led to increased e-book use. ${ }^{8}$ Likewise, Barbara Glackin, Roy Rodenhiser, and Brooke Herzog found that access to multipie mobile devices "significantly increased" how frequently a user accessed e-books. ${ }^{9}$ However, a study by Julie Gilbert and Barbara Fister at Gustavus Adolphus Col1s ge in St. Peter, Minnesota, found little correlation between such ownership and stuáent attitudes toward e-books. ${ }^{10}$

While many aspects of the role of e-books within libraries are fraught with controversy and disagreement, a number of findings appear to be coalescing. For example, users are more inclineal to turn to e-books than anecdotal evidence and professional intuition suggest. ${ }^{11}$ Many users regonize the benefit of the immediate, aroundthe-glack access that e-books provide..$^{12}$ In addition, uggrs view reference titles as especially well-suited for electronic formats. ${ }^{13}$ However, user awareness of the availability of e-books from academic libraries Users are more inclined to turn to e-books than anecdotal evidence and professional intuition suggest. is low. ${ }^{14}$ Another barrier to e-book adoption is that users are frustrated by the systems, platforms, and digital rights management (DRM) imposed by e-book publishers and aggregators. ${ }^{15}$ 


\section{Methodology}

The basis of this study was an online, self-selected survey, created using the Qualtrics online survey system. The survey consisted of fourteen multiple-choice and eight open-ended questions. Seven of the open-ended questions were conditional, requiring a specific answer to one of the multiple-choice questions to appear, so not every participant answered the same number of questions. The authors adapted the survey instrument from the one used in their 2012 study, with some adjustments based on the results of that earlier survey. ${ }^{16}$ One of the major changes involved removing the distinction between "academic" and "recreational" use of e-books, which failed to yield any significant results in the first study. The investigators modified a question about e-reader ownership to ask, instead, about which device(s) respondents used to read e-books. The new survey also changed an open-ended question- "What, if anything, would make you more likely to use e-books?"- to a multiple-choice question, using the analyzed responses from the first survey. Questions addressed the use of the oniysical library and online library resources, use of and attitudes about e-books, and preferences for print or e-books for various types of material (monographs, swecialized and general reference, citation manuals, conference proceedings, edited collections, and literature). Three demographic questions were included to allow comparisons by status (faculty, staff, graduate student, undergraduate student, or rese $\operatorname{coc}$ (n) affiliate), by college, and by department. A copy of the survey is included as Appefidix A and is also available online at http: / / ter.ps / e-book2014.

The survey remained open from October 1.to. November 22, 2014, and was advertised extensively across campus. Publicity efforts ircluded e-mail announcements distributed by subject librarians and the UMD Librofies communications office; the libraries' social media accounts; printed flyers posted in campus buildings; and handouts with the survey URL distributed in front of classroom buildings and the student union. The study was also advertised on the lib arles' home page. A grant from the University Libraries' Library Research Fund provfied financial support, which the authors used to purchase survey incentives in the form of one iPad Mini and eight \$25 Amazon.com gift cards. Prizes were prominenty featured in marketing materials that publicized the survey and were distributed ey random drawing, via a separate form linked from the end of the survey to mainzain respondents' anonymity.

The investigators exported the survey results to a Microsoft Excel spreadsheet and used IBNPSPS (Statistical Package for Social Sciences) 21, a software package for statisticânvestigations, to conduct descriptive statistics analysis and hypothesis testing. The Presearchers carried out a variety of tabulations using affiliate status and college Sffiliation as grouping variables. A common line of thinking, among both librarians and disciplinary faculty, suggests that scholars in the sciences, while more comfortable using materials in electronic formats, avoid using monographic materials in any format. Emblematically, one respondent to the survey commented, "I' $\mathrm{m}$ in science, nothing is in books, e-books or otherwise." To test these prevailing conceptions about the behaviors of researchers based on disciplines, the investigators grouped the twelve academic colleges and schools into "STEM" and "non-STEM" for comparison. The researchers listed the College of Agriculture and Natural Resources; the College of Computer, Mathematical, 
and Natural Sciences; the James Clark School of Engineering; and the School of Public Health as STEM. The remaining colleges and schools were classified as non-STEM.

The investigators calculated the correlations and conducted hypothesis tests for the correlations between visiting the physical library, using online resources, and use of e-books. In this survey, entering the physical library, use of online resources, and use of e-books are all ordinal scale data. Therefore, Spearman's rho, a statistic that indicates the closeness of the relationship between two variables, was used as the measure of association. For "check all that apply" questions, the investigators calculated the frequency for each option and used the "Aggregate" function in SPSS to create a list of possible combinations of choices with frequency to determine which combinations were more popular than others. The investigators recoded open-ended Questions 16 to 22 into eighteen different categories and recoded open-ended Question 24 into tyenty-two different categories (see Appendix B).

\section{Demographics}

In total, 2,188 people completed the survey. By college, the rargest percentage of responses came from the College of Computer, Mathematicalond Natural Sciences (15.7 percent); the College of Behavioral and Social Sciences (1 1 percent); the College of Arts and Humanities (10.7 percent); and the School of Public Health (9.7 percent). The fifth largest group (9.5 percent) chose "I am not affiliatied with a college," which required respondents to specify a campus unit. "Not affiliated" answers fell into four categories: academic support unit (for example, Undrorgraduate Studies), nonacademic support unit (for example, Health Center), research unit (for example, Division of Research), and Division of Information Technolegy.

By status, the largest percentase of responses came from graduate students (45.1 percent), followed by undergraduate students ( 31 percent), then staff ( 12 percent) and faculty (11.1 percent). Reseaph affiliates made up just 0.8 percent of respondents. Note that "staff" was not offered as an option in the 2012 survey, so those responses were combined with those of raculty in the previous study.

The investigatdrs excluded respondents who chose "University Libraries" (70) or "I am not affiliate with a college" (207) in comparative analysis of STEM and non-STEM respondent8Among the survey participants, 820 were classified as STEM and 1,091 as non-STEK 1 , for a total of 1,911 .

Cat of a total campus population of 47,209 , the overall response rate was 4.2 percent. Graauate students had the highest response rate at 9.22 percent, and undergraduates had the lowest at 2.56 percent. Faculty and staff response rates were 5.42 percent and 4.77 percent, respectively. Because exact enrollment numbers are difficult to obtain by college or department, the investigators did not calculate response rates by unit affiliation. Because of the low overall response rate, the potential for nonresponse bias is high. There should have been no "digital divide" among student and faculty participants and nonparticipants. Many university staff members (for example, facilities maintenance and housekeeping) lack easy access to e-mail or the Internet, since the university does not furnish them with computers and they often work in areas where computers are not available. Yet their response rate roughly equaled that of their faculty counterparts. 


\section{Table 1.}

\section{Responses by college affiliation}

\begin{tabular}{lcc}
\hline College & Frequency & $\begin{array}{c}\text { Valid } \\
\text { percentage }\end{array}$ \\
\hline
\end{tabular}

College of Agriculture and Natural Resources

\begin{tabular}{rr}
68 & 3.1 \\
88 & 4.0 \\
235 & 10.7 \\
255 & 11.7 \\
137 & 6.3 \\
343 & 15.7 \\
65 & 3.0 \\
197 & 9.0 \\
03 & 4.7 \\
115 & 5.3 \\
212 & 9.7 \\
93 & 4.3 \\
70 & 3.2 \\
207 & 9.5 \\
2,188 & 100.0 \\
\hline
\end{tabular}

Nonrespondents likely included those who do not regularly check e-mail (and thus missed the e-mail invitationS), who do not visit the libraries' website (and thus missed the news items), or whe do not regularly come to campus (and thus missed the posted flyers). Those who hoid extremely negative views of e-books may also have chosen not to respond, just as those who hold highly favorable views of e-books may have been eager to participate, leading to proportionally more positive responses. Those who were unmotivated by the survey prizes, either because they have no interest in an iPad or because they already own one, may also have chosen not to respond, though it is hard to preafit how this omission would affect the results. Other potential biases include selfselfoion effects, such as those introduced by offering a tablet computer and Amazon gift cards as survey incentives. People who were already disposed to using e-books (including shopping for them online) may have been more likely to take part in the survey, leading to more positive responses.

\section{Library Use}

The survey asked respondents how frequently they physically enter a campus library and how often they access online library resources. When examined together, the responses are consistent with a number of findings from the 2012 study. Across all affiliate statuses, 


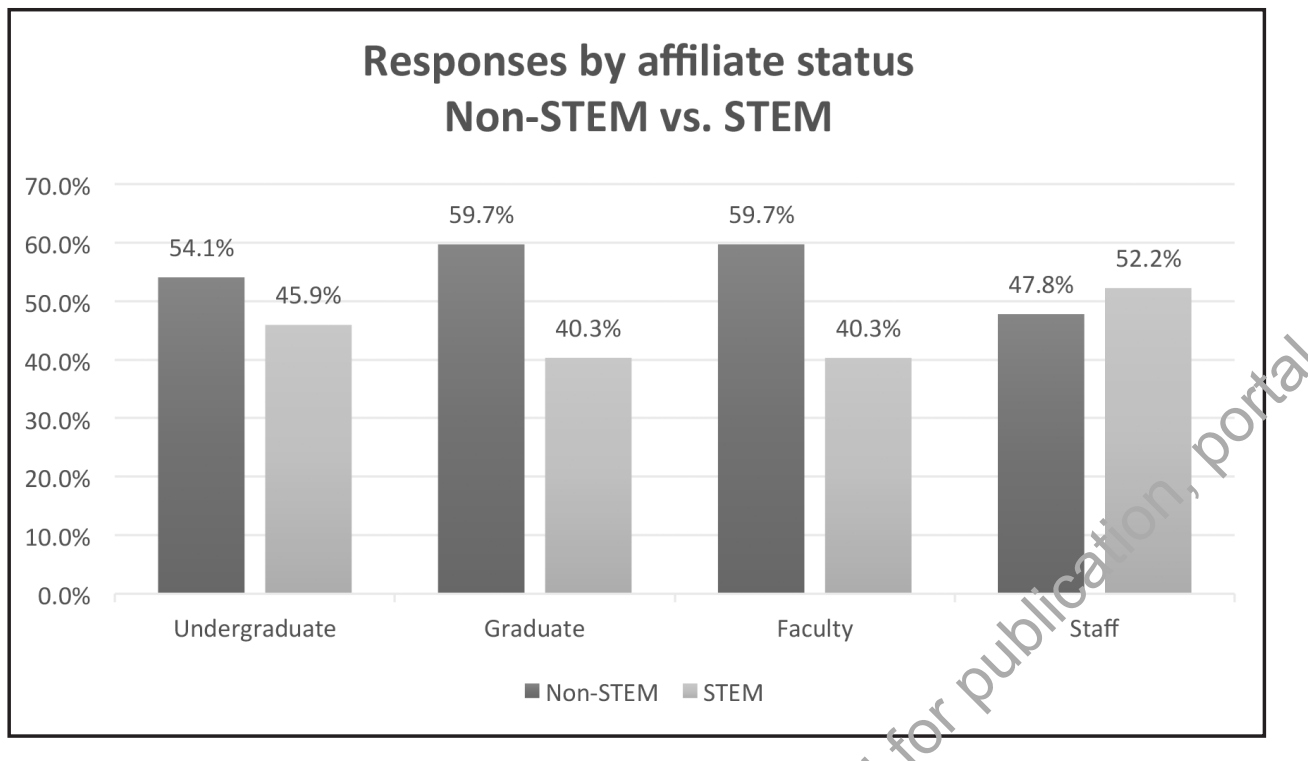

Figure 1. Responses by affiliate status, non-STEM versus STEM

respondents reported using online library resours $6 s$ more frequently than physically entering a campus library. This trend, in large partean be attributed to faculty and graduate student respondents, who said they used online library resources more frequently than they physically entered a campus library, with roughly 70 percent of both groups reporting daily or weekly online library res source use. On the other hand, undergraduates temain heavier users of physical library spacesewith 70.5 percent of respondents claiming to grter a campus library at least weekly. Only 41.3 . $\Theta$ rcent of undergraduate respondents reported daily or weekly use of online library resources. Theresults of the 2014 study show some noteworthy Hew findings, as well. Non-STEM respondents reported daily or weekly use of the physical library more frequently (51.7 percent) than

Non-STEM respondents reported daily or weekly use of the physical library more frequently (51.7 percent) than STEM respondents (42.8 percent). STEM 厄espondents (42.8 percent). However, nonSTEVI and STEM respondents reported daily and weekly use of online library resources afsimilar frequencies, 60.6 percent and 57.7 percent, respectively. Respondents who claimed to never enter the physical library, regardless of discipline and affiliate status, increased from 5 percent to 8 percent. ${ }^{17}$

\section{E-Book Use}

Reported use of e-books "for academic purposes" saw a noteworthy increase from the 2012 study. While 31 percent of respondents said they "never" used e-books for academic purposes in 2012, only 21.9 percent of participants selected that option in 2014. Moreover, 32.5 percent of 2014 respondents reported daily or weekly academic use of e-books. 
Undergraduates described the most frequent use of e-books for academic purposes (38.6 percent), followed by graduate students (37.2 percent), faculty (16.2 percent), and staff (14.2 percent). Faculty and staff were also the most likely to report "never" using e-books for academic purposes, at 33.1 percent and 47.7 percent, respectively. A larger proportion of STEM respondents acknowledged frequent use of e-books for academic purposes (38 percent) than non-STEM respondents (31.3 percent).

The response data indicate statistically significant but moderately weak-positive correlations between using the physical library spaces, using online library resources, and using e-books for academic purposes, with correlations of approximately 0.25 . To

\section{Respondents who reported frequent visits to the physi- cal library were more likely to report frequent use of online library resources and frequent use of e-books for academic purposes.} calculate these correlation coefficients, the inves tigators examined if the sample effect generalizes to the population by conducting a hyothesis test for whether Spearman's rho is ecpual to zero at the population level. Using SPSS the resulting output demonstrated that all three Spearman's rho measurements are statistically significant, at a significance level of 0.09 . Since the correlation coefficient in the population is non-zero, there is a statistically significant linear relation between the use of the physicg library, using online resources, and use of e-7gosks. This correlation indicates that respondents who reported frequent visits to the physical library were more likely to report frequent use of online library resourceg and frequent use of e-books for academic purposes. On the other hand, this also moans that users who admitted seldom visiting the physical library were less likely te feport frequently using online library resources or e-books for academic purposes

The survey also asked respohdents if their frequency of using e-books for academic purposes had increased, stay fat the same, or decreased compared to three years ago. Sixty-four percent reporteat that their use had increased during this period, while 34.2 percent said their use had stayed the same. Just 1.8 percent reported decreased use of e-books compared tol three years ago. These results show a substantial growth in the number of respondients reporting increased use (50 percent in 2012) and a substantial decrease in the number of respondents reporting that their use stayed the same (49 percent ig 2012). The inclusion of new colleges and schools in the current survey does not aprear to have caused the increase; a comparison of the three colleges surveyed in 2013 show that all three had increases in the percentages of respondents reporting that their use of e-books had grown. There was no significant difference between STEM and non-STEM responses in the survey.

\section{E-Book Access}

Respondents were asked to specify which devices, if any, they currently use to read ebooks. They were asked to select all that applied from a list of options: "Kindle," "Nook," "Other e-reader," "Tablet," "Mobile phone," "Computer," and "I don't use e-books." Participants who selected "I don't use e-books" were automatically prompted by Qual- 
trics to omit the subsequent five questions regarding how they access e-books. Among the respondents who read e-books, "Computer" was selected at the highest rate (72.5 percent), which could refer to either a laptop or desktop. The next most popular answers were "Tablet," "Mobile phone," and "Kindle," selected by 37.9 percent, 36.7 percent, and 25.6 percent, respectively. "I don't use e-books" was selected by 12.3 percent, and only 5.9 percent and 3.3 percent chose "Nook" or "Other e-reader," respectively. There were no significant differences between STEM and non-STEM respondents. Because respondents could choose more than one device, the investigators were able to analyze the most popular combinations of devices: 98 respondents chose the combination of "Tablet," "Mobile phone," and "Computer"; 93 participants chose "Mobile phone" and "Computer"; and 81 respondents chose "Tablet" and "Computer." Differences in question wording make it impossible to directly compare these results to those from 2012. That said, the general order of preference from 2012 was "Kindle," "Noot " "Tablet," "Phone," then "Laptop," so it is possible that e-readers are now used pijs frequently.

When asked for their primary source for accessing e-books, respondents selected "Commercial site" most frequently, at 35.9 percent. "Free websie" followed at 26.8 percent and "University of Maryland Libraries website" at 26. Percent. "Public library website" and "Other" received only 8.4 percent and 2.7 percent of responses, respectively. While "Commercial site" and "Free website" stayed relatively steady from the 2012 survey (31 percent and 30 percent, respective1 3 , the percentage of respondents choosing "University of Maryland Libraries wogsite" rose dramatically, up to 26.2 percent from 11 percent in 2012. "University (i) Maryland Libraries website" ranked as most popular among undergraduate studegets (29.5 percent), while staff chose it at the lowest rate (14.4 percent). Faculty and taff selected "Commercial site" at the highest rates (45.2 percent and 47.5 percent respectively), while graduate students chose "Free website" at the highest rate (30.1 site" at a higher rate than STEM respondents (39.7 percent versus 30.6 percent), while STEM respondents chose "fee website" at a higher rate (33.8 percent, versus 23.4 percent for non-STEM). The percentages of STE. choosing "University of Maryland Libraries website" were almost idenical. Although the question provided examples for both "Commercial site" (for example, Amazos, (Barnes \& Noble, or Google e-bookstore) and "Freg Quebsite" (for example, Google Books, HathiTrust

Some respondents may have been confused about the true source for most of the e-books they use. Digital Library, or Project Gutenberg), some respondents may have been confused about the true source for most of the e-books they use.

The survey also asked participants specifically how they discover and find e-books held by the UMD Libraries. The most frequent response was "Search the catalog or WorldCat" (45 percent); followed by "I don't use e-books from the UMD Libraries" (24 percent); and "Search for individual books in Research Port," the electronic portal to the UMD Libraries' databases (22 percent). "Search within a specific e-book collection" received the lowest number of responses (16 percent). Interestingly, not only were all four answers chosen in the same order as in the 2012 survey, but also there were no significant differences between STEM and non-STEM participants in the current survey. Thirty-nine 
respondents ( 2 percent) chose "Other, please specify" and provided additional free-text responses. Those responses most often mentioned Google or Google Scholar, which, if the user is on campus or logged in via the campus proxy authentication, link the user to a UMD-supplied e-book version if available. Other popular responses were variations of "I didn't know the libraries had e-books" or "I've tried looking for e-books from the libraries but couldn't find them." Others reported that they find UMD's e-books via professor recommendations, or by professors listing or directly linking to them via UMD's learning management system.

Respondents were also asked which e-book collections they had accessed through the UMD Libraries in the past year. The most popular choice was "I've used e-bogls

Many users do not know (or care) which publisher or vendor provides the content they need.

frequently were EBSCO e-book Collection (41 percent), I Ifyts (Institute of Electrical and Electronics Engineers) / Wiley e-books (20 percent), Sprifger e-books (19 percent), Oxford Handbooks Online (15 percent), ebrary (13 percents, Ghd Gale Virtual Reference Library (13 percent). With the exception of IEEE/Wiley edooks, which was not included last time because the focus was on researchers and students in non-STEM disciplines, these same collections were also the most popular in the 2012 survey, with EBSCO again at the top.

The survey queried respondents aloult how often they download e-books to a device for offline use, read e-books onling vera a website, or print at least a portion of e-books, and the responses showed some notable changes from the 2012 study. When asked how often they read e-books while Connected to the Internet, 8 percent of respondents in the 2012 study chose "never," 26 percent said "sometimes," and 35 percent answered "most of the time." In the 2019 study, these proportions changed to 5.3 percent (never), 36.6 percent (sometimes and 32.4 percent (most of the time). The findings of the 2014 study also suggest thatusers print out portions of e-books or entire e-books more frequently than in 2012. Ehile nearly 75 percent of respondents said they "never" or "rarely"

The ability to quickly and easily download an e-book in a common format (such as pdf) should be a critical feature of any e-book platform considered for purchase. printed out at least portions of e-books in 2012, that proportion fell to 67 percent in 2014. The most noteworthy change in reported behavior occurred in regard to downloading e-books for offline use. Respondents reporting that they downloaded e-books for offline use "frequently" or "always" remained relatively stable. However, while 52 percent of participants in the 2012 study said that they "never" downloaded an e-book to a device for offline use, in 2014 the percentage of respondents reporting "never" fell to 11.5 percent. Only

12.8 percent of participants in the 2014 study reported "rarely" downloading e-books 
for offline use. The clear majority reported at least sometimes downloading e-books to a device for offline use. These results indicate that the ability to quickly and easily download an e-book in a common format (such as pdf) should be a critical feature of any e-book platform considered for purchase. As one commenter explained:

I love having access to e-books, but I despise being forced to read them on my laptop screen. Some of them, for whatever reason, can't be downloaded. (I've gotten a message saying something like "you have to read this book online first" but then I never do find a way to download it.) I'm sure it's something about the rights, but it is maddening ... Otherwise, though, I think e-books are a great thing.

\section{E-books versus Print Books: Format Preferences}

Given the diverse range of materials that publishers now offer in electronic formats, both the 2012 and 2014 surveys asked users which types of material they prefer as print books over e-books, and vice versa. The question provided definitions for a variety of common academic materials-scholarly monographs, editedollections, conference proceedings, general and specialized reference, citation mathuals and style guides, and literature-before asking respondents to choose "I prefert\&int," "I prefer e-books," "No preference," or "It depends" for each. Participants yto selected "It depends" for any type of material were given the option to explain their response.

\section{Scholarly Monographs}

Compared to the 2012 survey, responderts's i overall preference for e-book scholarly monographs has risen only slightly (from 20 percent to 30 percent). However, their inclination for print has notably declined (frege 42 percent to 27.6 percent), and the percentage who say they have "no preference" rose sharply, fon 23 percent to 32.9 percent. The number of respondents who answered "It depends" remained the same, around 9 percent. Taken in aggregate, these humbers suggest that researchers may not wholpheartedly embrace e-books, but they are at least 16 sing their resistance to them and clinging less fightly to printed books. STEM respondents prefeferd e-books significantly more than non-STEM

Researchers may not wholeheartedly embrace e-books, but they are at least losing their resistance to them and clinging less tightly to printed books. respondents, 35.9 percent versus 28 percent, with a corresponding preference for print among non-STEM respondents (32 percent versus 22.7 percent). When cross-tabulated with respondent status, STEM graduate students had the overall highest rate of e-book preference at 41.3 percent, while non-STEM undergraduate students had the overall lowest rate of e-book preference at 19.4 percent.

\section{Edited Collections}

While overall preference for edited collections in e-book form rose slightly from 32 percent in 2012 to 33.6 percent in 2014, the respondents who chose "I prefer print" de- 
clined sharply (from 33 percent to 24.3 percent), and the number of participants with "No preference" rose from 24 percent to 33.1 percent. As with scholarly monographs, this seems to suggest a decreased resistance to e-books but not a new liking for them. STEM respondents favored e-book edited collections at a higher rate than non-STEM (38.5 percent versus 31.9 percent) and opted for print at a substantially lower rate (19.3 percent versus 28.7 percent). When cross-tabulated by respondent status, STEM faculty had the strongest preference for e-books (46.8 percent), and non-STEM undergraduates had the weakest preference for e-books (23.4 percent).

\section{Conference Proceedings}

Overall, respondents had a strong preference for e-books over print for conferenceproceedings, 45 percent to 14 percent. There was a slight increase in preference fèi e-books

Overall, respondents had a strong preference for e-books over print for conference proceedings,

\section{5 percent to 14 percent.} compared to the 2012 survey results (4) percent in 2012), while the percentage of "no pretsrence" stayed the same at 34 percent. STEM resporidents preferred e-book conference proceedings at a higher rate than their non-STEM counterpants, 48 percent to 38.8 percent, and favored print at a lower rate, 10.9 percent to 16 percent. Faculty reperted the strongest preference for conference profededings in e-book format, with 53.6 percent selectingthis option. Undergraduates had the weakest preference, with just 34.7 percent selfecting "I prefer e-books." STEM graduate students favored conference proceedings as 2 -books 62 percent of the time.

\section{General Reference}

Preference for general reference maierials decidedly favored electronic formats: 18.7 percent of respondents reported tey would rather have print, 28 percent had no preference, 46.2 percent said they preferred e-books, and 7.1 percent Preference for genera! " answered "It depends." While these results largely align reference materisis with the 2012 study, the 2014 study shows some variations between non-STEM and STEM respondents. Non-STEM decidedly favored respondents reported a slightly higher preference for print electronigformats: (22.3 percent) than STEM respondents (15.5 percent). Far more participants from both areas preferred general reference titles in e-format, with nearly half of participants from non-STEM (45.5 percent) and STEM (48 percent) liking e-books for such materials. NonSTEM faulty had the strongest preference for e-format (54.8 percent), while non-STEM undergraduates had the strongest preference for print (23.8 percent).

\section{Specialized Reference}

The preferred format for specialized reference materials also aligned with the 2012 results, with 20.3 percent of respondents favoring print, 28.6 percent having no preference, 42.5 percent favoring e-books, and 8.7 percent selecting "It depends." The results again show slight differences between STEM and non-STEM respondents, with 23.6 percent of 
non-STEM respondents reporting a preference for print specialized reference materials, as opposed to 16.8 percent of STEM respondents. As with general reference materials, participants from both areas favored specialized reference titles in e-format, with 46 percent of STEM respondents and 41.1 percent of non-STEM respondents indicating that preference. Non-STEM faulty had the strongest preference for e-format (47.8 percent), while non-STEM undergraduates had the strongest preference for print (25.0 percent).

\section{Citation Manuals and Style Guides}

As in 2012, 50.7 percent of respondents preferred the e-book format for citation manis als and style guides. In another example of decreased resistance to e-books, if no oull adoption, just 16.1 percent indicated a preference for print, down from 21 percent in 2012, and 27.2 percent selected no preference, up from 22 percent. That said inon-STEM respondents showed a stronger inclination toward print (19.8 percent $)^{2}$ than STEM respondents (11.6 percent). That inclination was evident in the selection of "No preference" as well, with non-STEM respondents staying consistent witto 2012 at 22.8 percent and STEM respondents a much more flexible 30.9 percent. Nop-STEM undergraduates showed the highest preference for print at 23.4 percent, while STEM graduate students, followed closely by non-STEM faculty, favor e-books at the highest rate (57.6 percent and 56.5 percent, respectively). This was the only typef material that garnered a majority of responses for either e-book or print, whichaligns with the results of the 2012 survey, justifying the purchase of citation manuals and style guides in electronic format, particularly if multiple users can access them at once.

\section{Literature}

The responses for literature, while slightly less polarized than the 18 percent gap between print and e-books in 2012, still showed a strong preference for print. Overall.40.4 percent would rather have print, 20.6 percent indicated no preference, 29.1 percent favor e-book Jand 9.9 percent selected "It depends." This was thue for both STEM and non-STEM, although STEM respondents did prefer e-books at the slightly hig@er rate of 43.7 percent, while non-STEM Many participants mentioned a desire for access to both the e-book and print versions of a title. respondents favored e-books at just 32.6 percent. NonSTEMalndergraduates showed the highest inclination for print at 47.8 percent, while STEM faculty had the highest preference for e-books at 36.4 percent.

\section{"It Depends"}

Respondents had the option to select "It depends" and explain their reasoning if they did not have a clear preference for e-books or print books. Many participants mentioned a desire for access to both the e-book and print versions of a title. Another common refrain was liking print for in-depth reading. No other trends emerged from the remaining comments. 


\section{Barriers to E-Book Use}

Respondents were asked what new features might make them more likely to use e-books so that the investigators could identify barriers to e-book use. The 2012 study asked a similar question, which solicited free-text responses that were coded and analyzed qualitatively. The 2014 study provided survey participants with a list of the most frequent answers from the 2012 study and asked them to select all that apply. Consequently, the percentage of respondents who identified a particular barrier to use in 2014 was much higher and cannot be compared directly with the 2012 results.

Despite this limitation, comparing the most frequently identified barriers from the two studies yields some interesting conclusions. In 2012, respondents identifieda

Users still do not always find the titles they seek. When they do find what they want, they frequently have difficulties navigating the perplexing combinations of interfaces and digital rights. dearth of e-book title availability in their aeas of interest and lack of e-reader ownership as substantial barriers to e-book use. In 2014 those barriers had dropped to fifth and seventh.respectively. In 2014 , users were more concerne d with the ability to download e-books to a device, the response moved from eighth in 2012 to fourth in 2014. Users have an increased interest being able to annotate and highlight e-books, fand that barrier moved from sixth in 2012 t $\sigma$ Second in 2014. The most consistent concerns and barriers to use were the limited findability and accessibility of e-books through the UMD Libraries website (third in 2012, first if 2014) and the cost of e-books from commercial vendors (fourth in 2012, third in 2014).

As in 2012, a portion of respondents said they "always prefer print books to e-books." Eight percent of participants in the current survey (compared to 4 percent in 2012) chose this response, with non-STEMrespondents much more likely than STEM respondents to select it (11 percent and 5 pefeent, respectively.) On the other end of the spectrum were survey participants why said they "already use e-books extensively or exclusively for academic purposes", 3.4 percent of participants in the current survey (compared to 2 percent in 2012) reorted frequent or exclusive use of e-books for such purposes.

The most 0 pular responses point to the continued challenges encountered by library users when trying to find, access, and use e-books, whether through the University Libraries or commercial vendors. Despite the increasing number of e-books available in the UMD Libraries collections, users still do not always find the titles they seek. When they do find what they want, they frequently have difficulties navigating the perplexing combinations of interfaces and digital rights.

When asked for additional comments or suggestions regarding e-books at the University of Maryland, free-text responses clustered around several themes identified as barriers to use earlier in the survey and mirrored the free-text comments from the 2012 survey. These comment themes include "General availability"; "Publicity/Training/Didn't know about e-books"; "Ease of access/use"; and "I already use e-books." Definitions of these and other coding categories are included in Appendix B. Also as in 2012, some respondents used the opportunity to express emotional or idiosyncratic views on e-books, for example: 


\section{Table 2.}

\section{Reported barriers to e-book use}

Answers to the question "What, if anything,
would make you more likely to use e-books
for academic purposes?"
If e-books were easier to find and access through
the UMD Libraries website
If e-books were easier to highlight or
annotate
If e-books from commercial vendors were
less expensive
If e-books were easier to download to
my device(s)
If there were more e-books available in my areas
$\quad$ of research interest
If more of my course textbooks were available
as e-books
If I owned a dedicated e-reader

Scientific evidence [shows] that people retain information better through the tactile process of reading a physicar book ... I will never be convinced that going completely digital is a good idea .... society tends to embrace new technology 100 [percent] before realizing the ramifications of a completely digital world. Do we ever learn from history?

\section{Conclusions}

Like the 2012 study, the results of this survey provide some insight into user preference for prinfor electronic reading and study materials. For an overview of the implications for ellection managers based on these results, see Table 3. Across all format types, unâforaduates showed the strongest preference for print, with faculty and graduate students showing a strong predilection for e-books except for scholarly monographs, edited collections, and literature. For scholarly monographs, undergraduates showed the strongest preference for print, with graduate

All three affiliate statuses indicated a clear inclination for literature titles in print. students and faculty indicating a slight inclination toward e-books. Undergraduates showed no clear preference for print or electronic versions of edited collections, while graduate students and faculty both expressed a 


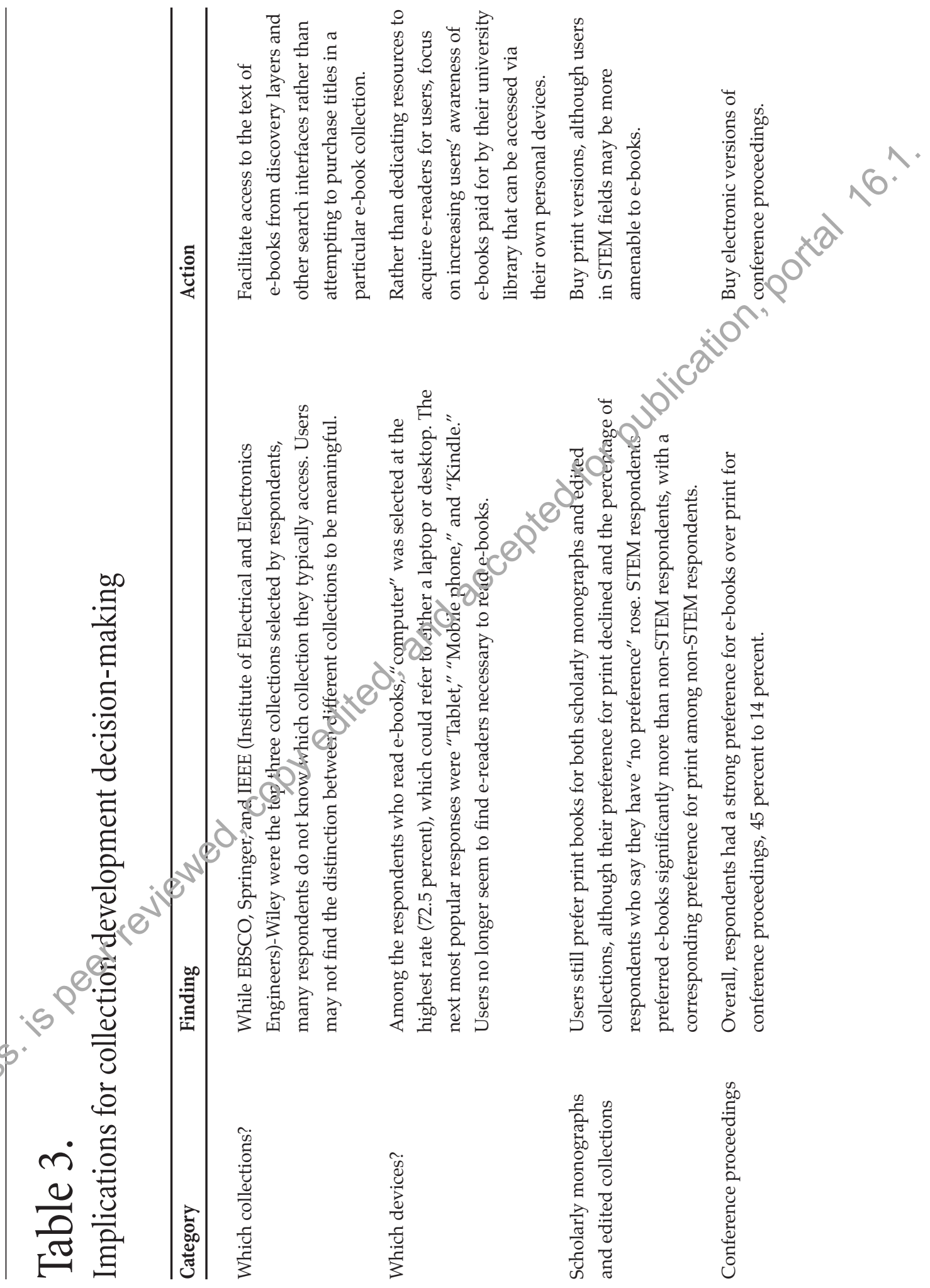



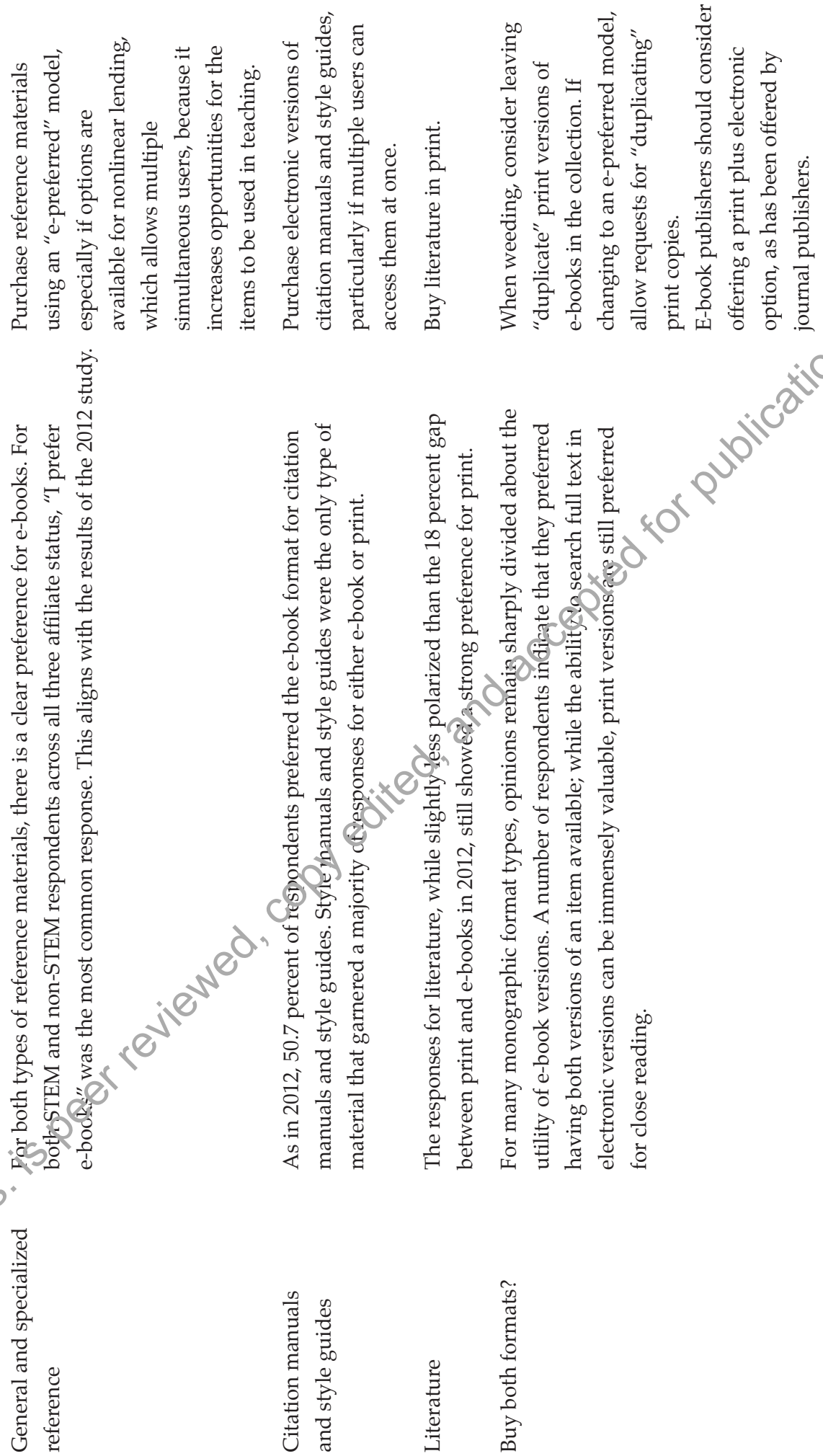


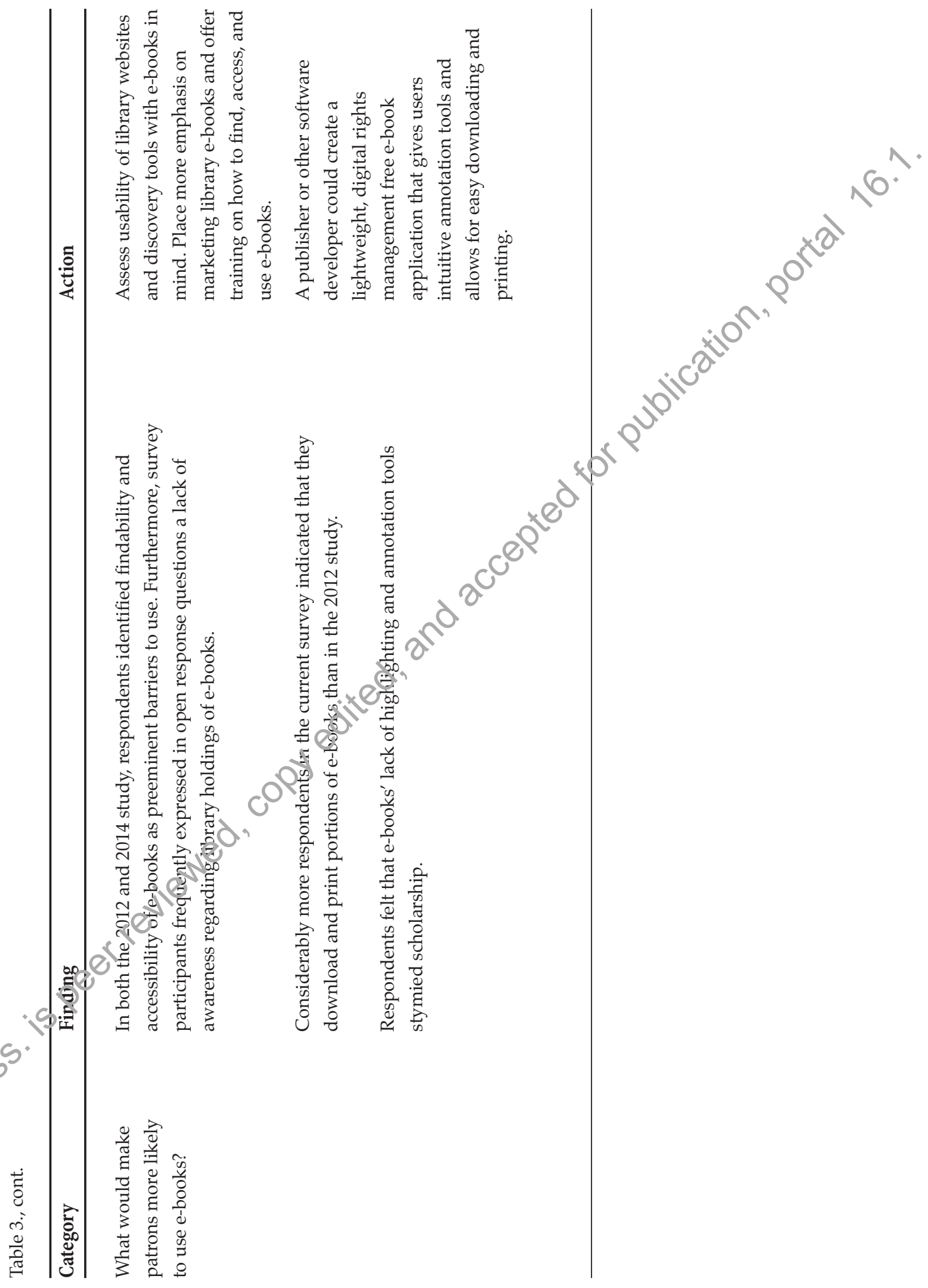


preference for electronic versions. All three affiliate statuses indicated a clear inclination for literature titles in print. For conference proceedings, reference materials, and style guides, the data suggest a clear preference for e-books across all affiliate statuses. For these format types, all affiliate statuses selected "I prefer e-books" as the most common response, with "No preference" as the second most common choice. In aggregate, these responses show a decreased resistance to e-books from that reported in the 2012 study and suggest a shift in leaning toward e-books for some types of material.

This study also provides a look at user preference for print or e-books by discipline, broadly speaking. In this study, non-STEM and STEM respondents' stated preference? for scholarly monographs and edited collections was divided equally among print, efetronic, and no preference. However, non-STEM respondents showed a slight inclination for print, while STEM respondents showed a slightly larger inclination for 11ectronic. However, neither result was definitive enough to generate a clear guide foppurchasing these formats. Both non-STEM and STEM users prefer electronic versiols ior conference proceedings, reference materials, and style guides. For all four types of materials, both STEM and non-STEM respondents selected "I prefer e-books" as tie most common response, with "No preference" as the second most frequent af wer and "I prefer print" coming in third. Meanwhile, literature predictably showed aclear divide between nonSTEM and STEM respondents: non-STEM users showe t a heavy preference for print versions of literature titles, while STEM participants were more equally divided between favoring print or e-book versions.

The findings of this study further corroborate the growing consensus that a large portion of academic library users across afiliate statuses and subject disciplines have grown comfortable with e-book version of conference proceedings, reference materials, and style guides. Users also increasirgly appreciate the access and additional features that these electronic versions progie. The results of this study join the chorus of previous studies' findings, making alstrong case for purchasing these types of materials using an "e-preferred" model. For naterials likely to be used for teaching and in classroom settings, such as specialifed reference materials and style guides, nonlinear lending licensing options thar allow multiple simultaneous users are worth considering.

For monographic materials, opinions remain sharply divided about the utility of e-book versions. A number of respondents indicated that they like having both versions of an item grvailable. While the ability to search the full toft of electronic versions of monographs can bejmmensely valuable, users still would rather have print versions for close reading. One possible solution is for publishers to offer a "print plus electronic" option, as journal publishers have done..$^{18}$ If a print copy came free with an e-book purchase or was bundled at a discounted

While the ability to search the full text of electronic versions of monographs can be immensely valuable, users still would rather have print versions for close reading. price, it would likely drive up e-book purchasing by academic libraries. With more libraries purchasing e-books, publishers could then dedicate the resources necessary to develop and maintain e-book platforms with more robust features, such as annotations and the freedom to print and download content, eliminating what users often identified as current barriers to adoption. 
The 2012 study concluded that e-reader ownership was an important factor for facilitating use of e-books, finding a correlation between e-reader ownership and e-book usage that other studies at the time corroborated..$^{19}$ However, the current study did not find a similar correlation between ownership of a dedicated e-reader and e-book usage, findings that align with other, more recent, e-book studies. ${ }^{20}$ Whether due to technological advances in the past three years, recruitment of a different group of survey participants, or changes in user behavior, users no longer seem to view e-reader access as a necessary

Users no longer seem to view e-reader access as a necessary step for using e-books. step for using e-books. Furthermore, participants in the 2014 study most often selected a computer, tablet, and smartphone as devices for accessing e-books; no e-reader of any type ranked among the top three options chosen. This sugges that libraries need not dedicate resources toward

acquiring e-readers. Rather, those resources should be directed toward increasing user awareness of e-books paid for by the university library that can be acdessed via users' personal devices.

Furthermore, considerably more participants in the currefisurvey indicated that they download and print portions of e-books than in the 200 study. While 52 percent of 2012 respondents reported that they "never" downloaded an e-book to a device for offline use, in 2014 those answering "never" fell to 11.5 percent. With only 12.8 percent of participants in the 2014 study said they "rarely" grownloaded e-books for offline use, the clear majority of respondents at least sometimnes download e-books to a device for offline use.

One exasperated respondent pointed y stated, "I absolutely DESPISE using e-books," pleading "please do not shift UMD's.res surces from print to e-books." Respondents felt that e-books' lack of highlighting arod annotation tools stymied scholarship. This individual continued: "E-books are difficult to use [because] when writing a dissertation, one needs to annotate bookscand use them in conjunction with many other sources and this is so hard to do with anl e-book." This complaint will no doubt interest librarians, because users are expeged to refrain from marking up the physical items loaned to them. Nevertheless, this contmon frustration suggests that e-books may become more popular among users if a publisher or other software developer can create a lightweight, DRM (digital rights fonagement)-free e-book application that provides intuitive annotation tools. However, studies also have suggested that, even when provided with robust options, yeers overestimate their use of annotation tools, leaving the importance of e-book anregtation up for further debate..$^{21}$

In both the 2012 and 2014 study, participants identified limited findability and accessibility of e-books as preeminent barriers to use. Furthermore, survey participants frequently expressed in open-response questions a lack of awareness regarding library holdings of e-books, with users suggesting that the UMD Libraries need to place more emphasis on marketing e-book collections and offer training on how to find, access, and use them. While the percentage of respondents who chose "University of Maryland Libraries website" as their primary source for e-books rose considerably from the 2012 study, this suggests that there are still issues regarding users' familiarity with the academic e-book ecosystem. While these issues could indicate generalizable challenges 
involving usability and lack of awareness of e-books, they also stand out as potential local issues related to UMD Libraries' website and discovery layer.

\section{Suggestions for Future Research}

To increase confidence and widen the applicability of this study's results, library and information science (LIS) researchers and practicing librarians could consider adopting this study's survey instrument and conducting a similar study at their home institutions. Other social science disciplines, such as some fields within psychology and political scin ence, have dealt with a crisis of confidence in the validity of research findings due to nonreplicable results. ${ }^{22}$ LIS research, which is often qualitative and conducted as case studies in single sites, suffers many of the same problems. LIS researchers and practicing librarians should endeavor to confirm the results of existing studies, such as this

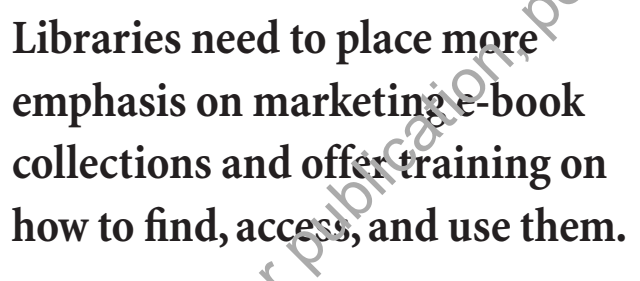

Libraries need to place mere emphasis on marketinge-book collections and offertraining on how to find, access, and use them. one, at their own institutions to increase the validity of the field's evidentiary literature.

As college and university libraries continually look for more quantitative measures of their impact on campuses, considerable attention tos turned to how libraries can increase student engagement, improve student learging, and lead to higher retention and matriculation rates. ${ }^{23}$ Although recent studies dy Barbara Glackin, Roy Rodenhiser, and Brooke Herzog as well as by Ee-Lon Lim and Khe Foon Hew suggest that e-books can positively impact student learning, more, research is needed to determine how library collections' acquisitions models, whon have become increasingly e-preferred, might affect these crucial assessment mettics and indicators. ${ }^{24}$

Perhaps the largest disagreement within the profession about e-books, and one not addressed within this study inges on whether academic libraries ought to acquire them at all given the current difficulties surrounding their access and acquisition. For example, Macalester College ir@t. Paul, Minnesota, while recognizing the potential value of ebook collections, bolleves that the current infrastructure and restrictions placed upon e-books "endarifers the ecosystem of sharing and does a disservice to our patrons and community. 25 Participants in this study's survey echoed those sentiments, with one recountirg the experience of trying to "set-up an e-book program ... with the library but [findiog it] very ... expensive and ... technically impossible." To address these issues, Macalester has published a set of standards it requires from publishers and vendors, and has urged other institutions to adopt these standards to put pressure on publishers to develop new infrastructures that facilitate access while remaining "respectful of copyright and fair use guidelines." ${ }^{26}$ Others have suggested that many of these problems result from e-books' relative nascence and can be expected to improve naturally over time, pointing to e-journals as a useful analogy. ${ }^{27}$ While initially unpopular and viewed with skepticism by many users, e-journals overcame low awareness and poor design to emerge as a foundational component of scholarly communication for many disciplines. ${ }^{28}$ Given this example, librarians should view their users' perceptions and adoption of ebooks within their academic communities as continually developing, rather than static 
and steadfast. With these expected changes in user behavior and the inevitable improvements for e-book platforms, continued research in this area will benefit the profession.

Alexander J. Carroll is the agriculture and natural resources librarian at the University of Maryland, College Park; he may be reached by e-mail at: ajcarrol@umd.edu.

Kelsey Corlett-Rivera is the head of Research Commons at the University of Maryland, College Park; her e-mail address is: kcr1@umd.edu.

Timothy Hackman is director of user services and resource sharing at the University of Maryland College Park; he may be reached by e-mail at: thackman@umd.edu.

Jinwang Zou is a doctoral student in Measurement, Statistics and Evaluation in the Leprortment of Human Development and Quantitative Methodology, College of Education, at Gie University of Maryland, College Park; his e-mail address is jwzou@umd.edu.

\section{Appendix A}

\section{UMD Libraries E-Books Surfey 2014}

http: / / ter.ps / e-book2014

Q1. What is your status at the University of Maryland?

- Undergraduate student

- Graduate student

- Faculty

- Staff

- Research affiliate

Q2. If you are affiliated witha college or the University Libraries, please select it from the list below.

- College of Agriculture and Natural Resources

- School of Architecture, Planning and Preservation

- Collegelof Arts and Humanities

- Colirege of Behavioral and Social Sciences

- Pobert H. Smith School of Business

- College of Computer, Mathematical, and Natural Sciences

(5) College of Education

- James Clark School of Engineering

- Philip Merrill College of Journalism

- College of Information Studies

- School of Public Health

- School of Public Policy

- University Libraries

- I am not affiliated with a college. (Please specify your unit below.) 
Q3. If you are affiliated with a department, please select it from the list below.

[Drop-down list of departments]

Q4. How often do you physically enter a campus library?

Daily

- At least once a week

- At least once a month

- At least once a semester

- At least once a year

- Never

Q5. How often do you access online library resources (databases, e-journals, e-bogks, catalog)?

- Daily

- At least once a week

- At least once a month

- At least once a semester

- At least once a year

- Never

Q6. What is an e-book?

For the purposes of this survey, an e-book is a book-le togth publication in digital form. E-books can be read on dedicated e-book readers (forefample, Kindle or Nook), personal computers, tablets, and some mobile phones. Notg that electronic journals, newspapers, and full-text archives (for example, Early Englist Books Online) are not considered e-books for the purposes of this survey.

Q7. How often do you use e-books for gcademic purposes?

- Daily

- At least once a week

- At least once a month

- At least once a semester

- At least once a year

- Never

Q8. Please complete the following statement: Compared to three years ago, my use of e-books forkacademic purposes has:

- Increased

- Strayed the same

- EDecreased

.99 What devices do you use to read e-books? (Check all that apply)

- Kindle

- Nook

- Other e-reader

- Tablet

- Mobile phone

- Computer

- I don't use e-books*

Note: If “I don't use e-books" was selected, respondents skipped to Q15. 
Q10. What is your PRIMARY source for the e-books you use?

- Commercial site (ex: Amazon, Barnes \& Noble, Google e-bookstore)

- Free website (ex: Google Books, HathiTrust, Project Gutenberg)

- Public library website

- University of Maryland Libraries website

- Other, please specify

Q11. How do you find e-books that are available from the UMD Libraries? (check all that apply)

- Search the catalog or WorldCat

- Search within a specific e-book collection (ebrary, EBSCO e-book Collection NetLibrary, Springer e-books, Safari Tech Books Online, etc.)

- Search for individual books in Research Port

- I don't use e-books from the UMD Libraries

- Other, please specify

Q12. Which of the following e-book collections (available from the University of Maryland Libraries) have you used in the past year? (check all thatapply)

- ABC-CLIO e-books

- Credo Reference

- ebrary

- EBSCO e-book Collection

- Gale Virtual Reference Library

- Handbooks in Economics (Elsevier)

- IEEE [Institute of Electrical and Electronics Engineers]/Wiley e-books

- OECD [Organisation for Economic Co-operation and Development] iLibrary

- Oxford Handbooks Online

- Safari Tech Books Online

- Springer e-books

- World Scientific e-books

- None of these

- I've used e-boglo from the UMD Libraries but I don't know which collection(s)

- Other, please pecify

Q13. When using e-books, how often do you:

[Choices: Nevei / Rarely / Sometimes / Most of the time / Always]

- Definnload to a device for offline use

- Read online (via a website, while connected to the Internet)

-9 Print all or a portion of the book?

Q14. In question 15, the formats [types of materials] are defined as follows:

Scholarly monograph: book-length, detailed study of a single subject, usually by a single author.

Edited collection: book on a single theme with one or more editors and chapters / essays on different subjects by different authors.

Conference proceedings: collection of papers from an academic conference.

General reference: Examples: Oxford English Dictionary, Encyclopædia Britannica, World Almanac, Bartlett's Quotations, etc. 
Specialized reference: Examples: subject encyclopedias (e.g., Oxford Encyclopedia of Economic History), research guides (e.g., MLA [Modern Language Association] Literary Research Guide), handbooks and manuals (e.g., Merck manuals), etc.

Citation manuals and style guides: Examples: Chicago Manual of Style, MLA Handbook, Publication Manual of the American Psychological Association [APA], etc.

Q15. Please indicate in what format you would prefer that the UMD Libraries purchase the following types of resources:

[Choices: I prefer print / No preference / I prefer e-books / It depends]

- Scholarly monographs

- Edited collections

- Conference proceedings

- General reference

- Specialized reference

- Citation manuals and style guides

- Literature (novels, short stories, poetry, etc.)

Note: Questions 16-22 only appeared for formats for which respondents chose "It depends" in Question 15.

Q16. Please explain why you chose "It depends" for "Scholarly monographs" in Question 15: [Open-ended comments box]

Q17. Please explain why you chose "It depends" fo "Edited collections" in Question 15: [Open-ended comments box]

Q18. Please explain why you chose "It depends" for "Conference proceedings" in Question 15: [Open-ended commengs box]

Q19. Please explain why you chose "in depends" for "General reference" in Question 15: [Open-ended comments boul]

Q20. Please explain why you chese "It depends" for "Specialized reference" in Question 15: [Open-ended comments box]

Q21. Please explain why Pou chose "It depends" for "Citation manuals and style guides" in Question 15: [Open-ended comments box]

Q22. Please explain why you chose "It depends" for "Literature (novels, short stories, poetry, etc in Question 15: [Open-ended comments box]

Q23. What, in anything, would make you more likely to use e-books for academic purposes? (Check all that apply.)

- If I owned a dedicated e-reader (for example, a Nook or Kindle).

- Uf I owned another device (for example, tablet or mobile phone) that could be used to read e-books.

- If e-books were easier to download to my device(s).

- If e-books were easier to find and access through the UMD Libraries website.

- If I had more training or knowledge on how to find, access, download, or use e-books.

- If e-books from commercial vendors (for example, Amazon) were less expensive.

- If there were more e-books available in my area(s) of research interest.

- If there were more e-books available in the non-English language(s) I read and/ or study.

- If more of my course textbooks were available as e-books. 
- If e-books were easier to print.

- If e-books were easier to highlight and/or annotate.

- If I knew more about how to cite information found in e-books / If the citation format(s) I use had better guidance for citing e-books.

- If e-books worked with my screen reader (or other adaptive technology for users with disabilities).

- If e-books were technologically improved (for example, better screen resolution, less reflective reading surface, longer battery life, etc.).

- If more e-books were available without digital rights management (DRM) restrictions.

- Nothing. I already use e-books extensively or exclusively for academic purnoses.

- Nothing. I will always prefer print books to e-books.

- Other, please specify:

Q24. Please share any additional comments or suggestions on e-books af the University of Maryland Libraries.

[Open-ended comments box]

University of Maryland Libraries E-Books Survey 2014 by Alex@der J. Carroll, Kelsey Corlett-Rivera, and Timothy Hackman is licensed unger a Creative Commons Attribution-Noncommercial 4.0 International License.

\section{Appendix B}

\section{Coding for Oper--Ended Questions}

*Unless indicated with an asterisk, Codes are identical to those used for data analysis in 2012.

Questions 16-22: Please ex 1 lain why you chose "It depends" for "format type" in Question 15:

Access: Respondent prefers whichever format is easiest to access, for example, print if he or she is already in the library, but e-book if he or she is online.

Both: Resporident would prefer to have both formats available.

Citationsis if the respondent expects to cite material from the book, he or she prefers print because citing e-books without page numbers can be difficult.

Cost: Respondent prefers whichever format is cheaper.

E-book features: Respondent prefers e-book features, such as full-text search, convenience, and the like.

E-book for scholarship: Respondent prefers to use e-books for scholarly reading and, vice versa, would rather have print books for leisure reading.

Formatting: Respondent indicated that e-books were preferred if the print formatting was preserved and the e-book was error-free. 
Illustrations: Respondent prefers print versions of books containing illustrations.

Lack of familiarity: Respondent was unable to make a determination due to lack of familiarity with the type of resource or the e-book format. Some respondents claimed it depends on the content, topic, area, and the like.

Length (in general): Respondent indicated that the length of the resource would influence which format was chosen but did not specify which format was preferred for any given length.

Long passage prefer e-book/Long passage prefer print book: Some respondents indicatea they would select an e-book when reading lengthy passages or a full book but wogld rather have print when reviewing short passages. Others declared the opposite- that is, they would rather have a printed book when reading lengthy passages or a (t) ull book but would prefer an e-book when reviewing short passages.

Mark-up: Respondent preferred print to be able to physically mark up the text (underline, highlight, add marginal notes, notate, and so on).

Navigation: Respondent indicated that it was more difficult to Glip through" an e-book to the notes or other sections, and therefore preferred print.

Ownership: Respondent preferred to purchase and onth hard copies of some titles but would favor e-books for titles he or she does not iniefid to keep.

Personal reasons: Respondent cited a personal reason, such as mood or feeling at the time, reading experience, or tangible things or the selection of print versus e-book.

Print for scholarship: Respondent preferred to use print works for scholarly reading and, vice versa, liked e-books for leistore reading.

*Frequency of usage: Respondent referred printed version if he or she believes it requires in-depth reading and he or she will use it frequently.

*Easy to copy: Respondeafpreferred whichever is easy to copy.

Question 24: Please share any additional comments or suggestions on e-books at the University of Marrland Libraries.

Already use e-books: Respondent is already using e-books for leisure reading, research, or both. For example, "I love my e-book readers and I take them everywhere"; "I use them a for leisure reading."

Citation: Respondent reported lack of page numbers or lack of standards for citing e-books âsa reason for not using them more. For example, "Consistency in page number[s]"; "If citation and page markings in e-books corresponded to their printed versions."

Convenience: Respondent indicated "Convenience" (without any further explanation) or mentioned portability of e-books, ability to access them without going to a library, or $24 / 7$ accessibility.

Depends on text: Respondent indicated a willingness to use e-books for certain purposes or with certain kinds of texts. For example, "I prefer e-books for shorter passages and print for larger ones"; "I prefer only to use them for reference"; "Books that I am unlikely to read more than once, but are not being used for research purposes." 
Don't like e-books/Prefer print: Respondent indicated a general preference for print books or a dislike of e-books, or said that he or she would only use e-books if there were no print equivalent available. (For example, “KEEP HARD COPIES. NO E-BOOKS!!!!!!!!!” or "I like holding a physical book, newsletter, article, etc. in my hands and turning the pages.")

Ease of access / use: Respondent indicated that e-book use would increase if electronic books were more user-friendly or declared that e-books are currently difficult to find, access, or use. For example, "If they were easy to find and access through the library website," "An incredibly friendly way to use them, more advanced than what is out now. Note: Also includes respondents who answered "Accessibility," though this response could also refer to greater availability (having larger numbers of e-books availabie).

E-book reader: Respondent would more likely use or read e-books if he or she owned an e-book reader (Kindle, Nook, or the like). Some answers mentioned iPads in obvious reference to the survey prize, for example, "If I won an iPad!"

Environment: Respondent indicated a preference for e-books over pint books because e-books do not use paper and are therefore more "sustainable."

Features: print/highlight/ annotate/ search: Respondent weold more likely use e-books for specific features, or if specific features were available. Respondents most frequently mentioned the ability to easily print, highlight text Grnnotate or write in margins, and search for specific words or phrases. Note that three of these features-highlighting, annotation, and searching-are available in oxisting e-book formats, while printing remains prohibited or problematic for moste books.

Greater availability: Respondent indicated a wish for a greater number or wider selection of available e-books, for examptel, "More choices." Also includes participants who indicated a desire for specific formats (such as "magazines," "research articles that are peer-reviewed," “audiobooks" (10r subjects ("literary theory," "linguistics," "biographies," "recreational reading," and the like).

Languages: Respondegtindicated a wish for greater availability of e-books in foreign languages generalles or in specific languages (such as Spanish).

Lower cost or frele: Respondent indicated that use of e-books would increase if they were free or cheaper than the print equivalent. Note that many responses seemed to conflate e-books rith e-book readers, and it was not always possible to tell whether the individual

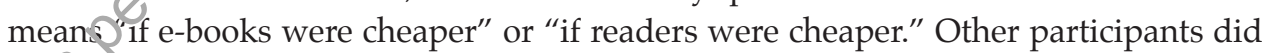
not Seem aware that the library lends e-books and e-book readers free of charge-for cxample, "E-books would be more feasible if there were not as many fees involved with using them, or if the readers were more affordable."

No response: No response or unusable response, for example, "Yes"; "If they made me fly."

Nothing/not sure: Respondent indicated "Nothing" or "Not sure" with no explanation.

Plan to use them more: Respondent indicated that he or she is currently not using e-books but has no objection to using them or will use them more in the future. 
Publicity / training/ didn't know about e-books: Respondent reported lack of awareness regarding library holdings of e-books, need for the UMD Libraries to do more publicity about e-book collections, or a willingness to use e-books if he or she had more knowledge of how to use them-for example, "Clear information about how to use. More publicity would help ... I never even knew these were available."

Technology improvements: Respondent mentioned specific improvements to e-book formats or readers that would make him or her more likely to use them-for example, clearer screens for less eyestrain, higher quality, open formats with no restrictions on what the user can do because of digital rights management (DRM).

Textbooks: Respondent would more likely use e-books if more textbooks were avaitable in e-format. Also includes participants who indicated that professors do notalión ereaders, laptops, and similar devices in the classroom, thereby inhibiting use of e-books for course texts.

Work with my device: Respondent would more likely use e-books if they were in a more compatible format (for example, pdf) or one that worked with a specific device (such as Kindle, Nook, iPad, or iPhone). Many respondents took his opportunity to reiterate their attitudes regarding e-books, with responses simin to those for Question 17. Therefore, we could use many of the same categories fot the answers to Question 18. A few additional categories were required to capture af the responses:

Acceptance: Respondent prefers print but reco gnizes that e-books will likely become more prevalent in the future and therefore is willing to adapt.

Both: Respondent indicated that he or she would prefer to have books available in both electronic and print formatefor example, print is easier to read, but e-books are easier to search so I would ike to have both options).

General positive response Respondent expressed a favorable opinion of the UMD Libraries, their services, or the survey itself.

\section{Notes}

1. Kelsey Corje ISRivera and Timothy Hackman, "E-Book Use and Attitudes in the Humanities, Social Sciences, and Education," portal: Libraries and the Academy 14, 2 (2014): 255-86, doi:10.1353/ pla.2014.0008.

2. Lav? Muir and Graeme Hawes, “The Case for E-Book Literacy: Undergraduate Students' Elperience with E-Books for Course Work," Journal of Academic Librarianship 39, 3 (May 2013): 260-74, doi:10.1016/j.acalib.2013.01.002; Erin Dorris Cassidy, Michelle Martinez, and Lisa Shen, "Not in Love, or Not in the Know? Graduate Student and Faculty Use (and Non-Use) of E-Books," Journal of Academic Librarianship 38, 6 (November 2012): 326-32, doi:10.1016/j.acalib.2012.08.005; Jodi1 Shepherd and Rachel Arteaga, "Social Work Students and E-Books: A Survey of Use and Perception," Behavioral E Social Sciences Librarian 33, 1 (January 2014): 15-28, doi:10.1080/01639269.2014.866022; Selinda Adelle Berg, Kristin Hoffmann, and Diane Dawson, “Not on the Same Page: Undergraduates' Information Retrieval in Electronic and Print Books," Journal of Academic Librarianship 36, 6 (November 2010): 518-25, doi:10.1016/j.acalib.2010.08.008; Leticia Camacho and Andy Spackman, "Transitioning to E-Books: Usage and Attitudes Among Business Faculty," Journal of Business \& Finance Librarianship 16, 1 (2010): 33-45, doi:10.1080/0 
8963568.2011.530856; Jody Bales Foote and Karen Rupp-Serrano, “Exploring E-Book Usage among Faculty and Graduate Students in the Geosciences: Results of a Small Survey and Focus Group Approach," Science E Technology Libraries 29, 3 (August 31, 2010): 216-34, doi:10.1080/0194262X.2010.497716; K. T. Anuradha and H. S. Usha, “Use of E-Books in an Academic and Research Environment: A Case Study from the Indian Institute of Science," Program: Electronic Library and Information Systems 40, 1 (January 1, 2006): 48-62, doi:10.1108/00330330610646807; James Bierman, Lina Ortega, and Karen Rupp-Serrano, "E-Book Usage in Pure and Applied Sciences," Science E Technology Libraries 29, 1-2 (March 9, 2010): 69-91, doi:10.1080/01942620903579393; Rajiv Nariani, "E-Books in the Sciences: If We Buy It Will They Use It?" Issues in Science and Technology Librarianship 59 (Fall 2009), doi:10.5062/F4WS8R5G; Heting Chu, "Electronic Books: Viewpoints from Users and Potential Users," Library Hi Tech 21, 3 (September 1, 2003):

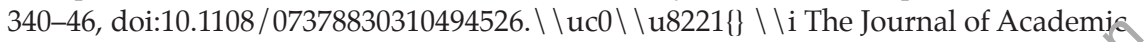
Librarianship \\i0\{\} 39, no. 3 (May 2013

3. Julie Waters, Jennifer Roach, Judith Emde, Scott McEathron, and Keith Russell, "4 Comparison of E-Book and Print Book Discovery, Preferences, and Usage by Sclence and Engineering Faculty and Graduate Students at the University of Kansas,' Ssues in Science and Technology Librarianship 75 (Winter 2014), doi:10.5062/F48G8HN5.

4. Michael Levine-Clark, "Electronic Book Usage: A Survey at the University of Denver," portal: Libraries and the Academy 6, 3 (2006): 285-99, doi:10.1353/pia.2006.0041; Ian Rowlands, David Nicholas, Hamid R. Jamali, and Paul Huntington, "What Do Faculty and Students Really Think about E-Books?," Aslib Proceedings 59, 6 (November 20, 2007): 489-511, doi:10.1108/00012530710839588.

5. Christina Mune and Ann Agee, "E-Book Showdown Lubluating Academic E-book Platforms from a User Perspective," in Creating Susturnable Community: The Proceedings of the ACRL 2015 Conference, ed. Dawn M. Mueller(Portland, OR, March 25-28, 2015), 218-24, http: / / www.ala.org/acrl/ sites / ala.ogs.acrl/ files / content/ conferences / confsandpreconfs/2015/Mune_Agee.pdc

6. ProQuest, "ProQuest Debuts Beta of Ney E-book Reader on Ebrary Platform," accessed January 6, 2015, http: / / www.proquest.com/about/news/2014/ProQuest-Debuts-Beta-ofNew-E-book-Reader-on-ebrary-F(attorm.html.

7. “Estimating Kindle E-Book Salds for Amazon," Forbes, April 2, 2014, accessed January 8, 2015, http: / / www.forbes.on/ sites / greatspeculations / 2014/ 04 / 02 / estimating-kindle-ebook-sales-for-amazon/.

8. Corlett-Rivera and Hackman, "E-Book Use and Attitudes in the Humanities, Social Sciences, and Education."

9. Barbara C. Gladym, Roy W. Rodenhiser, and Brooke Herzog, "A Library and the Disciplines: A Collaborative Project Assessing the Impact of E-Books and Mobile Devices on StudenlLearning," Journal of Academic Librarianship 40, 3-4 (May 2014): 299-306,

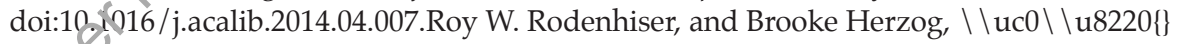
A Library and the Disciplines: A Collaborative Project Assessing the Impact of eBooks

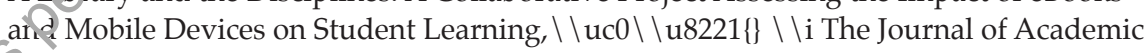

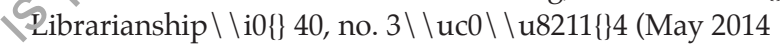

3). Julie Gilbert and Barbara Fister, "The Perceived Impact of E-books on Student Reading Practices: A Local Study," College E Research Libraries 76, 4 (May 1, 2015), http: / / crl.acrl. org/content/ early/2014/05/29/crl14-587.full.pdf+html.

11. David Nicholas, Ian Rowlands, David Clark, Paul Huntington, Hamid R. Jamali, and Candela Ollé, "UK Scholarly E-Book Usage: A Landmark Survey," Aslib Proceedings 60, 4 (July 6, 2008): 311-34, doi:10.1108/00012530810887962; Jeff Ellair, "Student Attitudes towards E-Books at UW-Sheboygan, and What Does It Mean to Us?" presented at Wisconsin Association of Academic Librarians (WAAL) Conference, Elkhart Lake, WI, April 24, 2013, http: / / sheboygan.uwc.edu/sites/sheboygan.uwc.edu/files/imce-uploads / library/about/policies/e-bookpresn.pdf; Gilbert and Fister, "The Perceived Impact of 
E-Books on Student Reading Practices: A Local Study"; Rowlands, Jamali, and Huntington, "What Do Faculty and Students Really Think about E-Books?”; Cynthia L. Gregory, “'But I Want a Real Book,'” Reference \& User Services Quarterly 47, 3 (March 1, 2008): 266-73, doi:10.5860/ rusq.47n3.266; Julia Linden, Angela Sidman, and Sarah Tudesco, "Ebrary on the Radar," in Mueller, Creating Sustainable Community, 225-35, http:/ / www.ala.org/acrl/ sites / ala.org.acrl / files / content / conferences / confsandpreconfs / 2015/Linden_Sidman_ Tudesco.pdf.

12. Ellair, "Student Attitudes towards E-Books at UW-Sheboygan, and What Does It Mean to Us?"; Glackin, Rodenhiser, and Herzog, "A Library and the Disciplines"; Nariani, "E-Books in the Sciences"; Hamid R. Jamali, David Nicholas, and Ian Rowlands, "Scholarly E-Books: The Views of 16,000 Academics: Results from the JISC [Joint Information Systems Committee] National E-Book Observatory," Aslib Proceedings 61, 1 (January 16, 2009): 33-47, doi:10.1108/00012530910932276; Jacqueline Ann Chelin, Jason Briddon, Elspeth Williams, Jane Redman, Alastair Sleat, and Greg Ince, "'E-Books Are Good If There Are NoCopies Left': A Survey of E-Book Usage at UWE Library Services," Library and Information Research 33, 104 (September 15, 2009): 45-65; Gregory, “'But I Want a Real Book.'”ReCenhiser, and

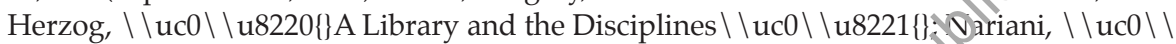
u8220\{\}E-Books in the Sciences \\uc0 \\u8221\{\}; Hamid R. Jamali, David Nicholas, and Ian Rowlands, \\uc0 \ \8220\{\}Scholarly E-Books: The Views of 16.000 Academics: Results

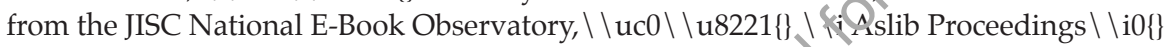
61, no. 1 (January 16, 2009

13. Chelin, Briddon, Williams, Redman, Sleat, and Ince, "'E-\$ooks Are Good If There Are No Copies Left"'; Corlett-Rivera and Hackman, "E-Boo'. Use and Attitudes in the Humanities, Social Sciences, and Education"; Gregefy" "But I Want a Real Book'”; Alain R. Lamothe, "Electronic Book Usage Patterns as Obqerved at an Academic Library: Searches and Viewings," Partnership: The Canadian Jourea of Library and Information Practice and Research 5, 1 (June 19, 2010), http: / / davin\&ib.uoguelph.ca/index.php/perj/article/ view / 1071. \\uc0 \\u8220\{\}E-Book Use and Attitudes in the Humanities, Social Sciences,

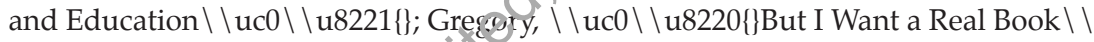

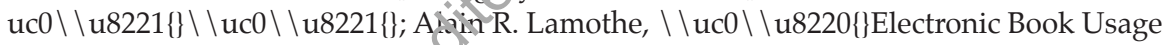
Patterns as Observed at an Acacemic Library: Searches and Viewings, $\backslash \backslash \mathrm{uc} 0 \backslash \backslash \mathrm{u} 8221\{\} \backslash \backslash \mathrm{i}$ Partnership: The Canadian folurnal of Library and Information Practice and Research $\backslash \backslash$ i0 \{\} 5, no. 1 (June 19, 2010

14. Ellair, "Student Attitudes towards E-Books at UW-Sheboygan, and What Does It Mean to Us?"; Corlett-Rìu and Hackman, "E-Book Use and Attitudes in the Humanities, Social Sciences, ald Education"; Alain R. Lamothe, "Factors Influencing the Usage of an Electroniçjook Collection: Size of the E-Book Collection, the Student Population, and the Fadulty Population," College \& Research Libraries 74, 1 (January 2013): 39-59; Levine Cárk, "Electronic Book Usage"; Waters, Roach, Emde, McEathron, and Russell, "A formparison of E-Book and Print Book Discovery, Preferences, and Usage by Science ard Engineering Faculty and Graduate Students at the University of Kansas"; Chelin, Priddon, Williams, Redman, Sleat, and Ince, “"E-Books Are Good If There Are No Copies Left'”; Noorhidawati Abdullah and Forbes Gibb, "Students' Attitudes towards E-books in a Scottish Higher Education Institute: Part 1," Library Review 57, 8 (September 5, 2008):

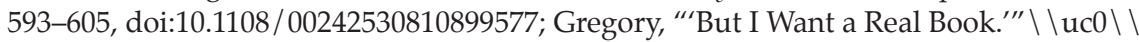
u8220\{\}E-Book Use and Attitudes in the Humanities, Social Sciences, and Education $\backslash \backslash$ uc0 \\u8221\{\}; Alain R.1, alamothe@laurentian.ca Lamothe, \\uc0 \ \8220\{\}Factors Influencing the Usage of an Electronic Book Collection: Size of the E-Book Collection, the Student Population, and the Faculty Population, $\backslash \backslash \mathrm{uc} 0 \backslash \backslash \mathrm{u} 8221\{\} \backslash \backslash \mathrm{i}$ College \& Research Libraries $\backslash \backslash \mathrm{i} 0\{\}$ 74, no. 1 (January 2013

15. Jolanda-Pieta (Joey) van Arnhem and Lindsay Barnett, "Is Digital Rights Management (DRM) Impacting E-Book Adoption in Academic Libraries?" Charleston Advisor 15, 3 (January 1, 2014): 63-65, doi:10.5260/ chara.15.3.63; Corlett-Rivera and Hackman, "E-Book 
Use and Attitudes in the Humanities, Social Sciences, and Education"; Glackin, Rodenhiser, and Herzog, "A Library and the Disciplines"; Nariani, "E-Books in the Sciences"; Chelin, Briddon, Williams, Redman, Sleat, and Ince, "'E-Books Are Good If There Are No Copies Left'”; Gregory, "'But I Want a Real Book'”; Kendall Hobbs and Diane Klare, "Exploring the Student E-Book Experience," in Mueller, Creating Sustainable Community, 251-57, http: / / www.ala.org/acrl/sites/ala.org.acrl/files / content/ conferences/confsandpreconfs / 2015/

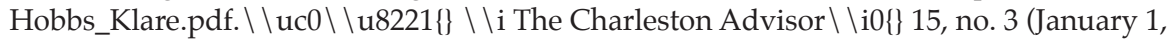
2014

16. Corlett-Rivera and Hackman, "E-Book Use and Attitudes in the Humanities, Social Sciences, and Education."

17. While it may be tempting to tie decreasing use of the physical library to increasing use of services such as document delivery, statistics at the University of Maryland show that su ci. requests have actually dropped since the time of the last survey. Interlibrary Loan filled an average of 740 requests per month in fiscal year 2013, which dropped to 389 per month in fiscal year 2015.

18. Wayne Bivens-Tatum, "A Modest E-Book Pricing Proposal," Academic Librariafu)June 18, 2015, https: / / blogs.princeton.edu/librarian/2015/06/a-modest-e-book-p 1ting-proposal/.

19. Corlett-Rivera and Hackman, "E-Book Use and Attitudes in the Humanities, Social Sciences, and Education"; Glackin, Rodenhiser, and Herzog, "A Library and the Disciplines."

20. Gilbert and Fister, “The Perceived Impact of E-Books on Student Reading Practices: A Local Study."

21. Hobbs and Klare, "Exploring the Student E-Book Experiegce."

22. Jens B. Asendorpf, Mark Conner, Filip De Fruyt, Jan De Houwer, Jaap J. A. Denissen, Klaus Fiedler, et al., "Recommendations for Increasing Replicability in Psychology," European Journal of Personality 27, 2 (March 1, 2013): 108-19. doi:10.1002/ per.1919.

23. Megan Oakleaf, The Value of Academic Libraries. A Comprehensive Research Review and Report (Chicago: Association of College and Research Libraries [ACRL], 2010); Krista M. Soria, Jan Fransen, and Shane Nackerud, "Library Use and Undergraduate Student Outcomes: New Evidence for Students' Retention at A' Academic Success," portal: Libraries and the Academy 13, 2 (2013): 147-64, doi:10.1353/ 119.2013.0010; Gaby Haddow, “Academic Library Use and Student Retention: A Quar litative Analysis," Library E Information Science Research 35, 2 (April 2013): 127-36, doi:19.1016/j.lisr.2012.12.002; Gaby Haddow and Jayanthi Joseph, "Loans, Logins, and Lasting the Course: Academic Library Use and Student Retention," Australian Academic \& Research Libraries 41, 4 (December 1, 2010): 233-44, doi:10.1080/00048 623.2010.10721478.

24. Glackin, Roderiyser, and Herzog, "A Library and the Disciplines"; Ee-Lon Lim and Khe Foon Hew, "Students' Perceptions of the Usefulness of an E-Book with Annotative and Sharing Caplabilities as a Tool for Learning: A Case Study," Innovations in Education and Teaching International 51, 1 (January 2, 2014): 34-45, doi:10.1080/14703297.2013.771969.

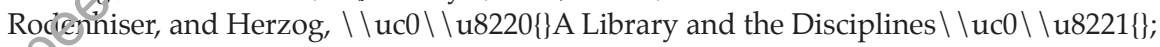

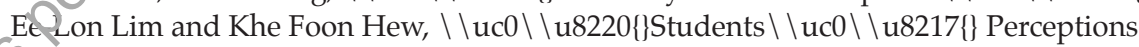
Of the Usefulness of an E-Book with Annotative and Sharing Capabilities as a Tool for Learning: A Case Study, \\uc0 $\backslash \backslash \mathrm{u} 8221\{\} \backslash \backslash \mathrm{i}$ Innovations in Education and Teaching International \\i0\{\} 51, no. 1 (January 2, 2014

25. DeWitt Wallace Library, Macalester College, St. Paul, MN, "E-Book Rights Advocacy," December 19, 2013, http: / / www.macalester.edu/library / changinge-booksforlibraries /

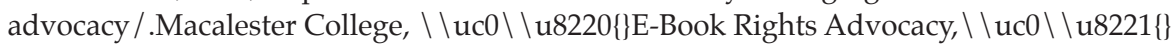
December 19, 2013, http: / / www.macalester.edu/library / changingebooksforlibraries / advocacy /.\}"," plainCitation":"DeWitt Wallace Library, Macalester College, "E-Book Rights Advocacy," December 19, 2013, http:/ / www.macalester.edu/library / changingebooksforlibraries/advocacy/."],"citationItems":[\{“id":1812,"uris":[“http:/ / zotero.org/users/1528109/items/BMUPT8Z6"],"uri":[“http: / zotero.org/ users/1528109/ 
items / BMUPT8Z6"],"itemData":\{“id":1812,"type":"post-weblog",,"title"::"E-Book Rights Advocacy","URL":"http: / / www.macalester.edu/library / changingebooksforlibraries / ad vocacy /", "author":[\{“family":"DeWitt Wallace Library, Macalester College", , given":"'\}] ,"issued":\{“date-parts":[[“2013",12,19]]\}\}\}],"schema":"'https:/ / github.com/ citation-stylelanguage/schema/raw/master/csl-citation.json"\}

26. Ibid.

27. Linda Ashcroft, "E-Books in Libraries: An Overview of the Current Situation," Library Management 32, 6/ 7 (2011): 398-407, doi:10.1108/01435121111158547.

28. Cecelia Brown, "Communication in the Sciences," Annual Review of Information Science and Technology 44, 1 (January 1, 2010): 285-316, doi:10.1002/ aris.2010.1440440114. 


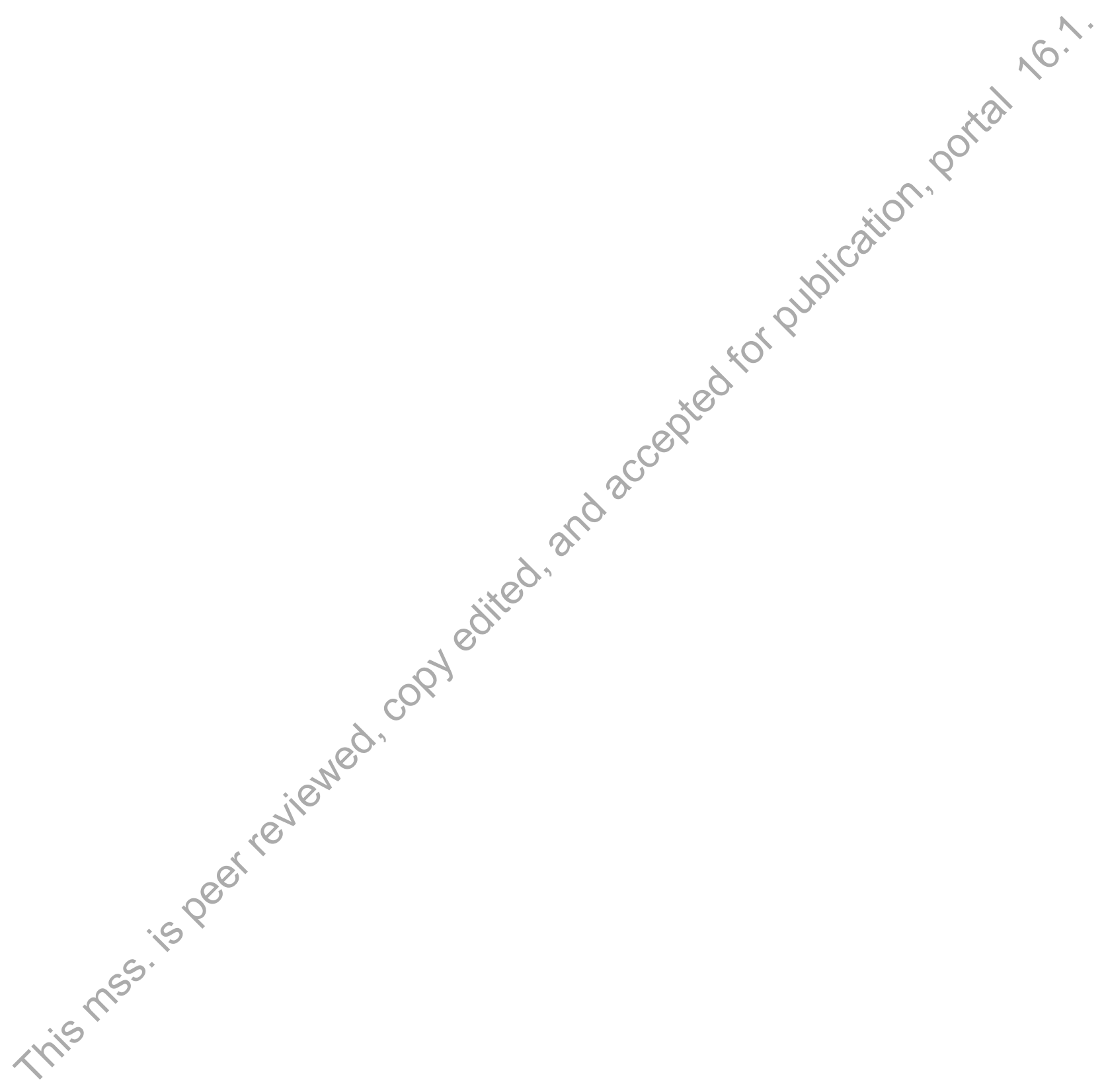

